\title{
EFEKTIVITAS PENEMPATAN PEGAWAI NEGERI SIPIL DI DINAS PENDAPATAN, PENGELOLAAN KEUANGAN DAN ASET DAERAH KABUPATEN BANYUASIN
}

\author{
Sahirrudin $^{1}$ \\ 1Badan Pengelola Keuangan dan Aset Daerah Kabupaten Banyuasin, sahirrudddin89@ gmail.com
}

\begin{abstract}
ABSTRAK
Karyawan merupakan kekuatan penggerak organisasi untuk mewujudkan fungsinya dan mencapai tujuan yang telah ditetapkan. Di saat ini ketika tantangan yang dirasakan semakin kompleks, keinginan organisasi publik untuk meningkatkan daya saing menuntut peningkatan kualitas karyawan yang proaktif terhadap gejolak dan perubahan. Dengan demikian, dapat dikatakan bahwa keberhasilan suatu tujuan organisasi sangat bergantung pada orang di balik senjata.

Penelitian ini menggunakan pendekatan penelitian kuantitatif dengan tingkat penjelasan deskriptif. Metode yang digunakan dalam pengambilan sampel adalah metode pengambilan sampel sensus atau anumerasi total lengkap dengan metode pengumpulan data yang mengambil setiap elemen populasi atau karakteristik yang ada dalam populasi tersebut. Jadi sampel dalam penelitian ini adalah seluruh Pegawai Tetap atau Pegawai Negeri Sipil Dinas Pengelolaan Pendapatan Daerah, Keuangan dan Kekayaan Daerah Kabupaten Banyuasin sampai tahun 2013. Yaitu sebanyak 37 orang. Data yang digunakan dalam penelitian ini adalah data primer dan data sekunder. Sedangkan teknik pengumpulan data dilakukan dengan metode angket, observasi dan dokumentasi. Teknik analisis data dilakukan dengan menggunakan perhitungan statistik deskriptif. Data tersebut dapat diuji dengan menentukan jawaban pada skor kuisioner, dimana skor tersebut dibagi menjadi 4 kategori, menggunakan skala likert, untuk mengetahui apakah penempatan SDM pada DPPKAD Kabupaten Banyuasin tergolong sangat afektif, efektif, tidak efektif. atau sangat tidak efektif. Hasil penelitian menunjukkan bahwa penempatan sumber daya manusia pada Dinas Pendapatan Untuk Pengelolaan Pendapatan Daerah. Keuangan dan aset Kabupaten Banyuasin termasuk dalam kategori cukup efektif secara keseluruhan. Hal ini terlihat dari bobot untuk keseluruhan indikator berdasarkan gradasi 102,7 yang menjadikan skor tersebut menunjukkan bahwa tingkat efektifitas penempatan sumber daya manusia pada Dinas Pendapatan Untuk Pengelolaan Pendapatan Asli Daerah, Keuangan dan Aset Kabupaten Banyuasin efektif dalam Secara kategori, indikator yang digunakan dalam penelitian tentang efektivitas penempatan pada Dinas Pendapatan Bagi Pengelolaan Pendapatan Asli Daerah, Keuangan dan Aset Kabupaten Banyuasin terdiri dari empat indikator yaitu Moralitas, Agresi, Kepemimpinan, dan Hubungan Manusia.
\end{abstract}

Kata Kunci: Efektivitas, Penempatan Sumber Daya Manusia

\begin{abstract}
Employees are the driving force of the organization to realize its functions and achieve predetermined goals. At this time when the perceived challenges are getting more and more complex, the desire of public organizations to increase competitiveness demands to improve the quality of employees who are proactive to any turmoil and change. Thus, it can be said that the success of an organizational goal is very much dependent on the man behind the gun.

This study used quantitative research approach with the level of descriptive explanation. The method used in sampling is a method of sampling of cencus or total anumeration complete the data collection method that takes each element of the population or characteristics present in the population. So the sample in this study are all permanent employees or the Civil Service Revenue Office For Management of Regional Revenue, Finance and Assets Banyuasin District until 2013. That as many as 37 people. Data used in this reseach is the primary data and secondary data. While data collecting
\end{abstract}


techinque done with the method of questionnaire, observation and documentation. The data analysis techique is done by using descriptive statistical calculations. Such data can be tested by determining the answers in the questionnaire scores, where scores were divided into 4 categories, using a likert scale, to determine whether whether the placement of human resources in the Revenue DPPKAD Banyuasin District classified as very affective, effective, ineffective or very ineffective. The results showed that the placement of human resources in the Revenue Office For Management of Regional Revenue. Finance and assets Banyuasin district, including in the category overall quite effective. It is seen from the weights for the overall indicator is based on the gradation of 102.7 which made the score showed that the level of effective of the placement of human resources in the Revenue Office For Management of Regional Revenue, Finance and Assets Banyuasin Regency effective in a category, indicators used in research on the effectiveness of placments in the Revenue Office For Management of Regional Revenue, Finance and Assets Banyuasin consists of four indicators namely Morality, aggression, leadership, and human relations.

Keywords: Effectiveness, Placement Of Human Resources

Naskah diterima : 18-06-2020, Naskah dipublikasikan : 30-09-2020

\section{PENDAHULUAN}

Berlakunya Undang-undang Nomor 32 Tahun 2004 tentang Pemerintahan Daerah sebagai payung hukum dan dijabarkan dalam persaturan pelaksanaannya untuk penyelenggaraan pemerintah di daerah, maka diharapkan pada masing-masing daerah untuk mampu melakukan perbaikan serta peningkatan kinerja dan kualitas sumber daya manusia atau aparatur melalui peningkatan kemampuan bekerja, berfikir dan keterampilan-keterampilan lainnya.

Sumber daya manusia (SDM) penting merupakan aspek bagin suatu organisasi, melalui sumber daya manusia suatu organisasi akan mampu berkembang dan sebaliknya, kehancuran sautu organisasi atau perusahaan dapat ditentukan sumber daya manusia. Konsep pengelolaan pegawai menjadi penting dalam organisasi, oleh karena itu organisasi tersebut harus berusaha untuk mendapatkan tenaga kerja yang sangat menentukan keberhasilan organisasi ada pendapat mengatakan: "sukses tidaknya suatu organisasi untuk bagian terbesar tergantung pada orang-orang yang menjadi anggatonya" (Suwnoto, 1981:134) dan hadits Abu Hurairah di dalam Shohih Bukhori dari Nabi SAW bersabda:

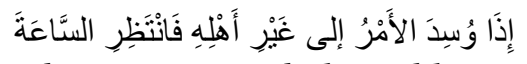

Artinya: Apabila diserahkan suatu urusan (tugas/pekerjaan) kepada orang yang bukan ahlinya, maka tunggulah saat (kegagalann/kehancuran) nya.

Rasulullah SAW juga bersabda, "Siapa yang mengangkat seseorang sebagai pegawai dari suatu kaum, padahal pada kaum itu terdapat seseorang yang diridhai Allah (cakap, soleh dan beriman) maka ia telah berkhianat kepada Allah, Rasul-Nya dan orang-orang beriman. (HR alHakim). Dalam rangka mencapai tujuan organisasi, bagaimanapun majunya teknologi, tersedianya modal kerja yang cukup serta peralatan yang memadai tidak akan berhasil tanpa didukung adanya kualitas sumber daya manusia sebagai pengelola kegiatan organisasi.

Pada Organisasi publik yang merupakan suatu wadah kegiatan dari orang-orang yang bekerja sama untuk mencapai suatu tujuan dalam hal mensejahterakan rakyat. Sehingga dalam kegiatan tersebut, setiap orang harus memiliki kejelasan tugas, wewenang, tanggung jawab, hubungan dan tata kerjanya, sehingga tujuan organisasi dapat tercapai. Pendapat para ahli mengatakan sebagai berikut:

Wewenang, Kewajiban dan tanggung jawab menjadi jelas, ini akan mencegah kekacauan, konflik kekuasaan, tumpang tindih pekerjaan dan kecendruangan saling melempar tugas, wewenang dan tanggung jawab apabila ada kemungkinan kesulitan.”(Iskandar, 1982) 
Organisasi publik diharapkan mampu memberikan pelayanan yang terbaik kepada masyarakat. Sehingga untuk mencapai tujuan tersebut, organisasi publik harus memiliki individu-individu dengan kualitas yang sesuai. Ambar T. Sulistiyani (2003) menyatakan bahwa: organisasi publik secara normatif lebih cenderung merupakan sebuah praktek dari model organisasi sistem tertutup. Ciri khas organisasi publik tidak berbeda dengan sejumlah karater yang memiliki oleh organisasi tertutup. Tampak organisasi publik berusaha menerapkan konsep birokrasi Weber, akan tetapi di dalam prakteknya banyak menjumpai permasalahan dan disfungsionalisasi sehingga tidak mampu mewujudkan efesiensi yang di idolakan Weber. Organisasi publik selanjutnya menjelma sebagai sebuah organisasi berstruktur tambun, kaku, inefesien dan sangat patologi (cacat). (Ambar Teguh, 2003).

Kualitas pegawai dapat dilihat dari pendayagunaan SDM dalam organisasi. Pendayagunaan tersebut antara lain dapat dilakukan melalui fungsi-fungsi perencanaan SDM, rekrutmen dan seleksi, penempatan SDM pengembangan SDM, perencanaan dan pengembangan karier, pemberian kompensasi, kesejahteraan, keselamatan maupun kesehatan kerja.

Organisasi baik publik maupun privat sangat memerlukan analisis jabatan dalam rangka mencapai tujuan organisasi, dimana analisis jabatan ini merupakan proses pengumpulan informasi tentang uraian pekerjaan dan persyaratan jabatan dalam melaksanankan pekerjaan, dalam rangka mewujudkan tujuan organisasi. Pegawai Negeri Sipil (PNS) sebagai unsur aparatur negara sekaligus pelaksana penyelenggaraan admnistrasi umun dan administrasi pembangunan berfungsi sebagai motor penggerak jalannya pemerintahan yang kuat, efektif, efesien dan akuntabel. Pegawai Negeri Sipil yang diperlukan bukan hanya yang memiliki keterampilan dan kemampuan profesionalis, melainkan juga diperlukan perubahan sikap mental dan yang memiliki etika dan moral yang tinggi serta dedikasi dan pengabdian kepada masyarakat. Dalam melaksanakan tugas pekerjaan atau jabatan agar berjalan dengan baik, sehingga penempatan Pegawai Negeri Sipil perlu diperhatikan. Upaya yang dapat mendukung hal tersebut adalan dengan terlebih dahulu melakukan analisis jabatan dalam oragnisasi pemerintah.

Kesesuaian penempatan pegawai dalam suatu organisasi merupakan suatu hal yang penting karena dalam pemberian pelayanan publik dibutuhkan aparatur pemerintah yang memiliki kualifikasi dengan profesionalisme yang sesuai. Oleh karenanya dalam penempatan pegawai haruslah tepat dan sesuai tuntutan pekerjaan dengan kualifikasi kemampuan dan profesionalismenya. Seseorang akan bekerja secara berdayaguna dan berhasil guna apabila mengetahui dengan jelas posisinya dalam suatu organisasi kerja. Kejelasan itu sangat penting artinya bagi setiap pegawai karena memungkinkan mengetahui peranan dan sumbangan pekerjaan terhadap pencapaian tujuan kerja secara keseluruhan.

Penempatan pegawai harus berpegang kepada prinsip "The right man on the right place and the right man on the right job" yang artinya penempatan orang-orang yang tepat pada tempat dan untuk jabatan yang tepat. Prinsip tersebut menggambarkan suatu kondisi dimana efektivitas penempatan ini sangat mewarnai organisasi-organisasi yang menghargai kualitas dan kompetensi, dan organisasi-organisasi tersebut percaya bahwa hanya dengan melakukan penempatan pegawai yang sesuai dengan prinsip komptensi dan kualitas, diharapkan akan meningkatkan kinerja pegawai sehingga tujuan organisasi dapat tercapai.(Kurniadi, 2003).

Menempatkan orang pada tempat yang tepat memang sangat menguntungkan. Mereka bekerja dengan lebih efesien dan efektif. Akan tetapi, seringkali penempatan ini dipolitir karena kepentingankepentingan tertentu, dengan menempatkan orang-orang yang disenangi pada posisi-posisi kunci (penting) atau "basah" (banyak kegiatan, program atau proyek). Disini tidak hanya prinsip efesiensi dan efektivitas dilanggar, tetapi juga prinsip transparansi dan akuntabilitas. Dengan kata lain jika suatu diserahkan kepada yang bukan ahlinya maka organisasi tersebut maka organisasi tersebut tinggal menunggu kehancurannya. 
Keadaan Pegawai Negeri Sipil (PNS) di Indonesia telah menunjukan keadaan yang kurang sehat sejak periode pemerintah Presiden Soeharto. Akan tetapi hal tersebut tidak mengurangi minat banyak orang untuk menjadi seorang PNS. Kondisi tersebut dapat merangsang munculnya rebutan atau persaingan tidak sehat untuk menduduki jabatan tinggi. Salah satunya yang menjadi persoalan PNS yakni pelaksanaan manajemen kepegawaian yang tidak sesuai dengan analisis jabatan (job analysis) (Prof. Dr. Eko Prasojo 2006), ini menyebabkan bahwa dari 3,6 juta PNS kita saat ini tidak jelas benar apa sebenarnya job analysis (analisis jabatan) dan apa sebenarnya yang harus mereka kerjakan. (http://yosefkoton.blogspot.com/2006/08/birokrasi-oleh-yosef-p.html)

Untuk mendapatkan pegawai yang produktif yang menjadi persoalan utama adalah setiap pegawai pada pekerjaan dan jabatan yang sesuai dengan bakat, minat dan kemampuan agar dapat bekrja secara wajar sesuai kemampuan, keahlian dan atau keterampilan serta latar belakang pengalaman dan pendidikan. (Musanef, 1996). Selain itu pula dalam upaya mendapatkan pegawai yang profesional dan bertanggungjawab, bersih dan berwibawa, disiplin dan etos kerja yang produktif serta menjunjung tinggi kejujuran, kebenaran dan keadilan, perlu adanya sistem pemanfaatan dan penempatan setiap pegawai pada pekerjaan artau jabatan sesuai dengan bakat, minta dan kemampuan keahlian dan atau keterampilan serta latar belakang pengalaman, guna mencapai hasil yang sebaikbaiknya.

Proses penempatan pegawai yang tidak tepat akan menyebabkan kinerja yang kurang optimal. Adapun pola penempatan pegawai di Bagian Pendapatan Dinas Pengelolaan, Pendapatan Keuangan dan Aset Daerah (DPPKAD) Kabupaten Banyuasin dapat dilihat dari kondisi pegawai yang dimilikinya. Jumlah Pegawai Negeri Sipil berdasarkan tingktan pendidikan yang berada di Bagian Pendapatan DPPKAD Kabupaten Banyuasin dapat dilihat pada tabel berikut:

Tabel 1. Jumlah Pegawai Negeri Sipil Bagian Pendapatan DPPKAD Kabupaten Banyuasin Berdasarkan Tingkat Pendidikan

\begin{tabular}{|l|l|l|}
\hline No. & Pendidikan & Jumlah \\
\hline 1 & Pasca Sarjana/S2 & 6 \\
\hline 2 & Sarjaana/S1 & 15 \\
\hline 3 & Diploma III & 3 \\
\hline 4 & SLTA/SMK & 13 \\
\hline \multicolumn{2}{|l|}{ Iumlah } & 37 \\
\hline
\end{tabular}

Sumber: Bagian Kepegawaian DPPKAD Kabupaten Banyuasin

Tabel 1. memperlihatkan bahwa penempatan dari segi pendidikan Pasca Sarjana/S2 dan S1, pendidikan SLTA/SMK, dan jenjang pendidikan Diploma III dengan jumlah minoritas. Kondisi ini merupakan potensi yang membutuhkan perhatian lebih untuk dikembangkan mengingat arti pentingnya sumber daya manusia sebagai aset jangka panjang.

Namun demikian tidak semua pegawai Bagian Pendapatan DPPKAD Kabupaten Banyuasin memiliki latar belakang pedidikan ekonomi atau keuangan. Beberapa pegawai diketahui justru memiliki latar belakang pendidikan hukum, Ilmu Politik, Ilmu Sosial dan Ilmu Lainnya. Sehingga dengan kata lain, penempatan pegawai di Bagian ini masih belum sesuai dengan kompetensi yang dimilikinya.

Dengan melihat kondisi tersebut, maka penting untuk menganalisis sejauhmana pengaruh penempatan pegawai negeri sipil di Bagian Pendapatan DPPKAD Kabupaten Banyuasin. Pengkajian ini akan menelaah informasi yang dapat dijadikan dasar yang kuat bagi pengambil keputusankeputusan yang berkaitan dengan sumber daya manusia. 


\section{HASIL DAN PEMBAHASAN \\ Hasil Penelitian}

Hasil penelitian mengenai efektivitas penempatan sumber daya manusia di bagian Pendapatan DPPKAD Kabupaten Banyuasin ini didasarkan pada empat indikator yang ada dalam penelitian ini. Keempat indikator tersebut adalah moralitas, agresifitas, kepemimpinan serta human relations. Masing-masing indikator terdiri dari beberapa sub indikator dan 17 item pertanyaan.

Analisis tentang efektivitas penempatan sumber daya manusia di Bagian Pendapatan DPPKAD Kabupaten Banyuasin ini dimulai dengan mengalaisis setiap item (sub indikator) yang ada dalam setiap indikator. Setelah setiap item dalam satu indikator dianalisis, kemudian skor keseluruhan item (bobot) dalam saru indikator tersebut dicari rata-rata untuk mengalisis efektivitas penempatan SDM dari setiap indikator. Setelah semua indikator diukur kinerjanya kemudian total skor keseluruhan dari 4 indikator yang ada dalam penelitian ini dicari rata-ratanya untuk menemtukan efektivitas penempatan SDM khususnya efektivitas penempatan sumber daya manusia (SDM) di Bagian Pendapatan DPPKAD Kabupaten Banyuasin.

Jumlah skor tertinggi untuk setiap item $=4 \times 37=148$. Jumlah skor terendah untuk setiap item $=1 \times 37=37$. Untuk menetukan penempatan SDM di Bagian Pendapatan DPPKAD Kabupaten Banyuasin, setiap itemnya adalah pertama dengan menentukan intervalnya terlebih dahulu. Rumus yang digunakan untuk menetukan interval adalah:

$$
\mathrm{I}=\frac{\text { Range }}{\mathrm{K}}
$$

Keterangan:

I $\quad:$ Interval/Rentang kelas

Range : Skor tertinggi - skor terendah

$\mathrm{K} \quad$ : Banyak Kelas yang ada

Berdasarkan rumus penentuan interval tersebut, maka interval untuk setiap item adalah sebagai berikut:

$$
I=\frac{148-37}{4}=\frac{111}{4}=27,8
$$

Jadi untuk setiap item indikator gradasi efektivitas organisasi dalam melakukan penempatan SDM dapat diukur sebagai berikut:

$$
\begin{aligned}
\text { Bobot } & 37-64,8 & =\text { Sangat tidak Efektif } \\
\text { Bobot } & 65-92,8 & =\text { Tidak Efektif } \\
\text { Bobot } & 93-120,8 & =\text { Efektif } \\
\text { Bobot } & >121 & =\text { Sangat Efektif }
\end{aligned}
$$

Pengukuruan mengenai efektivitas dalam melakukan penempatan SDM di Bagian Pendapatan DPPKAD Kabupaten Banyuasin ini dilakukan dengan menyebar kuisioner kepada 37 orang responden untuk menjawab pertanyaan mengenai efektivitas penempatan SDM yang dilakukan. Selanjutnya setelah semua kuesioner terkumpul dilakukan edit data, mengkode dan mentabulasi data untuk menentukan apakah penempatan SDM di Bagian Pendapatan DPPKAD Kabupaten Banyuasin tergolong sangat efektif, efektif, tidak efektif dan sangat tidak efektif. 
Tabel 2. Status Responden berdasarkan Latar Belakang Pendidikan

\begin{tabular}{|l|l|l|l|}
\hline No. & Pendidikan Terakhir & Jumlah & Persentase(\%) \\
\hline 1 & < SMU & - & - \\
\hline 2 & SMU & 13 & 35,14 \\
\hline 3 & DI/DII/DIII & 3 & 8,11 \\
\hline 4 & S1 & 15 & 40,54 \\
\hline 5 & S2/S3 & 6 & 16,22 \\
\hline \multicolumn{2}{|l|}{ Jumlah } & 37 & 100 \\
\hline
\end{tabular}

Sumber: Data Primer

Berdasarkan data tabel 2. dijelaskan bahwa Karateristik responden berdasarkan tingkat pendidikan dalam penelitian ini mayoritas memiliki latar belakang pendidikan S1. Persentase terbanyak kedua adalah mereka yang memiliki latar belakang pendidikan Sekolah Menengah Umum (SMU), S2/S3, lalu sebanyak 16, 22\% dan yang lain berlatar belakang pendidikan DI/DII/DIII.

Tabel 3. Status Responden Peneliti berdasarkan Jenis Kelamin

\begin{tabular}{|l|l|l|l|}
\hline No. & \multirow{2}{*}{ Status } & Jenis Kelamin \\
\cline { 3 - 4 } & & Laki-laki & Perempuan \\
\hline 1 & PNS & 21 & 16 \\
\hline 2 & CPNS & - & - \\
\hline 3 & Honorer & - & - \\
\hline Jumlah & 21 & 16 \\
\hline
\end{tabular}

Sumber: Data Primer

Berdasarkan data tabel 3. terlihat bahwa karakteristik responden berdasarkan jenis kelamin, mayoritas berjenis kelamin laik-laki yakni sebanyak 21 orang sedangkan 16 orang lainnya berjenis kelamin wanita.

Berikut identitas responden berdasarkan usia yang akan dijelaskan pada tabel berikut:

Tabel 4. Status Responden Peneliti berdasarkan Usia

\begin{tabular}{|l|l|l|l|}
\hline No. & Usia & Jumlah & Persentase (\%) \\
\hline 1 & $20-25$ Tahun & 4 & 10,81 \\
\hline 2 & $26-30$ Tahun & 15 & 40,54 \\
\hline 3 & $31-35$ Tahun & 7 & 18,92 \\
\hline 4 & $36-40$ Tahun & 5 & 13,51 \\
\hline 5 & 41-45 Tahun & 3 & 8,12 \\
\hline 6 & $>$ Lebih dari 45 Tahun & 3 & 8,12 \\
\hline Jumlah & 37 & 100 \\
\hline
\end{tabular}

Sumber: Data Primer

Berdasarkan data pada tabel 4. terlihat bahwa responden dalam penelitian berdasarkan usia. Sebagian besar dari mereka yaitu sebesar $40,54 \%$ berusia antara 26-30 tahun, sedangkan yang memiliki usia antara 41-45 tahun hingga lebih dari 45 tahun hanya sebesar 8,12\% atau masing-masing hanya sebanyak 3 orang saja.

Berikut akan dijelaskan hasil penelitian mengenai efektivitas penempatan Sumber Daya Manusia khusunya pada efektivitas penempatan Sumber Daya Manusia di Bagian Pendapatan DPPKAD Kabupaten Banyuasin, sebagai berikut: 


\section{Tingkat Moralitas}

Berikut tabel 5. yang memuat data dari hasil jawaban responden mengenai Tingkat Moralitas. Berkenaan dengan tingkat moralitas dalam penempatan pegawai di Bagian Pendapatan DPPKAD Kabupaten Banyuasin.

Tabel 5. Jawaban Responden mengenai Tingkat Moralitas

\begin{tabular}{|l|l|l|}
\hline Tingkat Persetujuan & Frekuensi & Bobot \\
\hline Sangat Setuju & 2 & 8 \\
\hline Setuju & 14 & 42 \\
\hline Tidak Setuju & 15 & 30 \\
\hline Sangat Tidak Setuju & 6 & 6 \\
\hline Jumlah & 37 & 86 \\
\hline
\end{tabular}

Berdasarkan data tabel 5., skor untuk tingkat Moralitas dalam rangka penempatan Sumber daya manusia di bidang Pendapatan sebesar 86. Ditinjau dari rentang skor (bobot) yang ada untuk setiap item mengenai Tingkat Moralitas dapat dikatan berada dalam kategori Tidak Stuju, dalam hal ini dapat dikatakan bahwa sebagian besar pegawai tidak setuju jika sistem penempatan pegawai di Bidang Pendapatan sudah bersih dan jujur dari netotisme, kolusi maupun kedekatan dengan pemimpin.

\section{Tingkat Agresifitas}

Sub indikator Tingkat Agresifitas berkenaan dengan penempatan pegawai yang telah memperhatikan prestasi kerja pegawai yang bersangkutan serta memperhatikan pengembangan jabatan pegawai. Berikut tabel 6. yang memuat data dari hasil jabatan responden berkenaan dengan adanya perhatian terhadap prestasi kerja pegawai yang bersangkutan berkenaan dengan tingkat agresifitas dalam rangka penempatan sumber daya manusia di Bagian Pendapatan.

Tabel 6. Jawaban Responden mengenai Tingkat Agresifitas

\begin{tabular}{|l|l|l|}
\hline Tingkat Persetujuan & Frekuensi & Bobot \\
\hline Sangat Setuju & 2 & 8 \\
\hline Setuju & 14 & 48 \\
\hline Tidak Setuju & 15 & 30 \\
\hline Sangat Tidak Setuju & 6 & 4 \\
\hline Jumlah & 37 & 90 \\
\hline
\end{tabular}

Berdasarkan data pada tabel 6. skor untuk Tingkat Agresifitas dalam rangka penempatan Sumber daya manusia di bidang Pendapatan sebesar 90. Ditinjau dari rentang skor (bobot) yang ada untuk setiap item mengenai Tingkat Agresifitas dapat dikatan berada dalam kategori Tidak Stuju, dalam hal ini dapat dikatakan bahwa sebagian besar pegawai tidak setuju jika sistem penempatan pegawai di Bagian Pendapatan telah memperhatikan prestasi kerja pegawai dalam hal ini bagian dari tingkat agresifitas dalam melakukan penempatan pegawai.

\section{Tingkat Kepemimpinan}

Sub indikator Tingkat Kepemimpinan berkenaan dengan dengan peran pimpinan dalam membimbing pegawai selama bekerja serta penghargaan yang diberikan pimpinan terhadap hasil kenirja pegawai sehingga pegawai termotivasi dan bersemangat dalam bekerja.

Berikut tabel 7 .yang memuat data hasil jawaban responden berkenaan dengan adanya peran pimpinan dalam membimbing pegawai selama bekerja. Hal ini berkenaan dengan tingkatan kepemimpinan dalam rangka penempatan pegawai. 
Tabel 7. Jawaban Responden mengenai Tingkat Kepemimpinan

\begin{tabular}{|l|l|l|}
\hline Tingkat Persetujuan & Frekuensi & Bobot \\
\hline Sangat Setuju & 17 & 68 \\
\hline Setuju & 14 & 35 \\
\hline Tidak Setuju & 2 & 4 \\
\hline Sangat Tidak Setuju & 1 & 1 \\
\hline Jumlah & 37 & 108 \\
\hline
\end{tabular}

Berdasarkan data pada tabel 7. skor untuk Tingkat Kepemimpinan dalam rangka penempatan Sumber daya manusia di bidang Pendapatan sebesar 108. Ditinjau dari rentang skor (bobot) yang ada untuk setiap item mengenai Tingkat Kepemimpinan dapat dikatan berada dalam kategori Setuju, dalam hal ini dapat dikatakan bahwa sebagian besar pegawai Setuju jika pemimpin sangat berperan penting untuk membimbing pegawai selama bekerja dalam rangka penempatan pegawai.

\section{Human Relations}

Berikut tabel 8. yang memuat data hasil dengan jalinan hubungan dan komunikasi yang baik antara pegawai dengan atasan maupun rekan kerja di bagian Pendapatan Kabupaten Banyausin.

Tabel 8. Jawaban Responden mengenai Tingkat Kepemimpinan

\begin{tabular}{|l|l|l|}
\hline Tingkat Persetujuan & Frekuensi & Bobot \\
\hline Sangat Setuju & 18 & 72 \\
\hline Setuju & 16 & 48 \\
\hline Tidak Setuju & 2 & 4 \\
\hline Sangat Tidak Setuju & 1 & 1 \\
\hline Jumlah & 37 & 125 \\
\hline
\end{tabular}

Berdasarkan data pada tabel 8. skor untuk Human Relations dalam rengka penempatan sumber daya manusia sebesar 125. Dintinjau dari rentang skor (bobot) yang ada untuk setiap item mengenai Human Relations dapat dikatakan berada dalam kategori Sangat Setuju, dalam hal ini dapat dikatakan bahwa sebagian besar pegawai sangat setuju jika penempatan sumber daya manusia di bagian pendapatan kabupaten Banyuasin saat ini telah memotivasi pegawai untuk bekerja dengan baik.

Dari keseluruhan item dalam indikator tersebut maka rata-rata dari keempat indikator tersebut adalah 102,7, berdasarkan rentang skor yang ada dapat dikatakan bahwa tingkat Moralitas, Agresifitas, Kepemimpinan serta Human Relations dalam rangka efetivitas penempatan sumber daya manusia di bagian Pendapatan DPPKAD Kabupaten Banyuasin termasuk kategori Efektif.

Berikut akan dianalisis mengenai tingkat efektivitas dari keseluruhan indikator. Secara keseluruhan jumlah bobot dari 4 indikator apabila dirata-rata akan diperoleh bobot sebesar 102,7 (rangkuman lihat di tabel 9).

Tabel 9. Hasil Pengukuran Efektivitas Penempatan Sumber Daya Manusia Secara Keseluruhan

\begin{tabular}{|l|l|l|}
\hline Aspek yang Diukur & $\begin{array}{l}\text { Hasil } \\
\text { Pengukuran }\end{array}$ & Bobot \\
\hline & & \\
\hline Tingkat Efektivitas Kepribadian & & \\
\hline Tingkat Moralitas & Tidak Setuju & 86 \\
\hline Tingkat Agresifitas & Tidak Setuju & 92 \\
\hline Tingkat kepemimpinan & Setuju & 108 \\
\hline Tingkat Human Relations & Sangat Setuju & 125 \\
\hline
\end{tabular}




\begin{tabular}{|l|l|l|}
\hline Aspek yang Diukur & $\begin{array}{l}\text { Hasil } \\
\text { Pengukuran }\end{array}$ & Bobot \\
\hline Rata-rata Indikator & Efektif & $\mathbf{1 0 2 , 7}$ \\
\hline & & \\
\hline Rata-rata Bobot & Efektif & 102,7 \\
\hline
\end{tabular}

Sumber: Diolah dari data Primer

Berdasarkan hasil penelitian terlihat bahwa efektivitas penempatan SDM di Bagian Pendapatan DPPKAD Kabupaten Banyuasin, secara keseluruhan termasuk dalam kategori efektif. Hal tersebut terlihat dari bobot untuk keseluruhan indikator yaitu 102,7, dimana berdasarkan gradasi yang dibuat skor tersebut menunjukan bahwa tingkat efektivitas penempatan SDM di Bagian Pendapatan DPPKAD Kabupaten Banyuasin berada dalam kategori efektif. Lebih lanjut dapat dilihat dari 4 indikator dengan 13 sub indikator yang diukur, 3 item diantaranya termasuk dalam kategori sangat setuju, 5 item termasuk dalam kategori setuju serta 5 item termasuk dalam kategori tidak setuju.

Dari penjelasan diatas hasil pengukuran penelitian tingkat efektivitas penempatan SDM di Bagian Pendapatan DPPKAD Kabupaten Banyuasin termasuk pada kategori efektif, dimana bobot yang diperoleh dari rata-rata indikator tersebut adalah 102,7.

Kategori Sangat Efektif dalam indikator ini berkenaan dengan Tingkat Efektivitas Motivasi, meliputi: Dorongan terhadap Pekerjaan, Tujuan Bekerja, Pentingnya dorongan serta Hal yang disukai. Kategori Efektif dalam indikator ini berkenaan dengan Tingkat Efektivitas Pengalaman dan Pengetahuan yang meliputi: Tingkat Moralitas, Tingkat Agresifitas, Tingkat kepemimpinan serta Tingkat Human Relations. Sedangkan untuk kategori tidak efektif, berkenaan dengan indikator Tingkat Efektivitas Intelektual, yang meliputi Tingkat Kecerdasan Khusus serta Tingkat Kemampuan Memecahkan Masalah.

\section{PENUTUP}

\section{Simpulan}

Penempatan sumber daya manusia di Bagian Pendapatan DPPKAD Kabupaten Banyuasin, secara keseluruhan termasuk dalam kategori efektif. Indikator yang digunakan dalam penelitian mengenai efektivitas penempatan sumber daya manusia di bagian Pendapatan DPPKAD Kabupaten Banyuasin terdiri dari Tingkat Moralitas, Tingkat Agresifitas, Tingkat Kepemimpinan serta Tingkat Human Relations. Namun demikian temuan hasil peneliti menunjukkan bahwa dari empat indikator terdiri dari Tingkat Moralitas, Tingkat Agresifitas, Tingkat Kepemimpinan serta Tingkat Human Relations termasuk kategori efektif,

\section{Saran}

Saran yang diberikan pada penelitian ini bertujuan untuk memperbaiki dan meningkatkan efektivitas penempatan SDM di Bagian Pendapatan Dinas Pendapatan, Pengelolaan Keuangan dan Aset Daerah Kabupaten Banyuasin. Adapun saran yang dapat diberikan penulis berdasarkan hasil penelitian antara lain memperhatikan latar belakang pendidikan dan pengetahuan yang dimiliki oleh seorang pegawai dengan jabatan atau pekerjaan dalam penempatan pegawai sesuai dengan tempatnya (the right man in the right place), memperhatikan pengembangan jabatan pegawai dalam suatu penempatan jabatan serta memberikan pendidikan/pelatihan/Bimtek, memberikan suatu sistem penghargaan baik berupa kompensasi, promosi jabatan, maupun kenaikan pangkat serta perhatian dan penghargaan dari atasn kepada bawahan agar pegawai termotivasi terus sehingga dapat meningkatkan kinerjanya, menerapkan adanya suatu standar kompetensi dalam penempatan pegawai, dimana standar kompetnsi tersebut meliputi kompetensi dasar dan kompetensi bidang yang dimiliki oleh setiap pemegang jabatan meliputi integritas, kepemimpinan, perencanaan, dan pengorganisasian, kerjasama dan fleksibilitas. Sedangkan untuk kompetensi bidang dipilih dari kompetensi yang tersedia sesuai dengan bidang pekerjaan yang menjadi tanggung jawabnya. 


\section{REFERENSI}

Arep, Ishak dan Tanjung, Hendri, 2002. "Manajemen Motivasi” Jakarta: Universitas Trisakti.

Bedjo Siswanto. 1989. "Manajemen Tenaga Kerja". Bandung: Sinar Baru.

Burhannudin A. Tayibnapis. 1995. "Administrasi Kepegawaian: Suatu Tinjauan Analitik". Jakarta: PT Pradnya Paramita.

Dessler, Gary. 1997. "Manajemen Sumber Daya Manusia. Terjemahan, Benyamin Molan. Edisi Bahasa Indonesia”. Jakarta: PT Prenhallind.

Gomes, Faustino Cardaso. 2001. "Manajemen Sumber Daya Manusia". Yogyakarta: Penerbit Andi Affset.

Hasibuan, Malayu. SP. 2002. “Manajemen Sumber Daya Manusia: Dasar dan Sosial”. Jakarta: Departemen Ilmu Administrasi FISIP UI.

Hidayat. 1986. "Teori Efektifitas Dalam Kinerja Karyawan" Yogyakarta: Gajah Mada University Press.

Iskandar, Suharto. 1982. "Pengantar Organisasi dan Manajemen". Surakarta: FISPOL Universitas Negeri Surakarta.

Mathis. L.R dan Jackson, J.H. 2001. "Manajemen Sumber Daya Manusia (Human Resource Management)". Jakarta: PT. Salemba Empat.

Mangkuprawira, Sjafri. 2002. "Manajemen Sumber Daya Strategik". Jakarta: Ghalia Indonesia.

Musanef. 1996. "Manajemen Kepegawaian di Indonesia". Jakarta: PT Toko Gunung Agung.

Munir, Rinaldi. 2004. "Pengolahan Citra Digital dengan Pendekatan Algoritmik". Bandung: Informatika,

Samsudin, Sadili. 2005. “Manajemen Sumber Daya Manusia”. Bandung: Pustaka Setia.

Siagian, Sondang P. 2003. “Manajemen Sumber Daya Manusia: Cetakan 10” Jakarta: Bumi Aksara.

Sulistiyani, Ambar Teguh, dkk. 2003. "Manajemen Sumber Daya Manusia: Konsep, Teori dan Pengembangan Dalam Konteks Organisasi Publik". Yogyakarta: PT Toko Graha Ilmu.

Sugiyono. 1994. "Metode Peneliti Administrasi”. Bandung: CV. Alfabeta.

\section{Peraturan Perundangan:}

Undangan-undang Republik Indonesia Nomor 43 Tahun 1999 Tentang Perubahan UU Nomor 8 Tahun 1974 Tentang Pokok-pokok Kepegawaian;

Undang-undang No. 32 Tahun 2004 Tentang Pemerintah Daerah;

Peraturan Pemerintah Republik Indonesia Nomor 100/2000 Tentang Pengangkatan PNS dalam Jabatan Struktural;

Peraturan Pemerintah Republik Indonesia Nomor 100/2002 Tentang Perubahan PP Nomor 100/2000 Tentang Pengangkatan PNS dalam Jabatan Struktural;

Keputusan kepala (Kepka) BKN No. 13 Tahun 2002 Tentang Ketentuan pelaksanaan

\section{Sumber Hadits:}

Hadits Abu Hurairah di dalam Shohih Bukhori.

Hadits Riwayat al-Hakim.

\section{Sumber lainnya:}

(http://yosefkoton.blogspot.com/2006/08/birokrasi-oleh-yosef-p.html) 